\title{
Comparison of Ionic Association between Tertiary and Quaternary Ammonium Carboxylates in $\gamma$-Butyrolactone
}

\author{
Makoto UE*, Sachie SEKIGAWA, Masayuki TAKEDA and Shoichiro MORI \\ Received April 18, 1994 ; Accepted July 15, 1994
}

\section{INTRODUCTION}

The conductometric analysis of nonaqueous electrolytes ${ }^{1.3)}$ containing $\gamma$-butyrolactone (GBL) solvent has been focused on tetraalkylammonium and alkali metal salts of strong acids ${ }^{410}$, particularly on the lithium salts such as $\mathrm{LiClO}_{4}, \mathrm{LiBF}_{4}, \mathrm{LiPF}_{6}$ and $\mathrm{LiAsF}_{6}$, because $\gamma$-butyrolactone is an important dipolar aprotic solvent used for high energy lithium batteries.

On the other hand, tertiary and quaternary ammonium salts of carboxylic acids in $\gamma$-butyrolactone have been used as liquid electrolytes in aluminum electrolytic capacitors ${ }^{11-14}$.

In the previous paper ${ }^{13}$, we have reported the conductometric analysis on the quaternary ammonium carboxylates in $\gamma$-butyrolactone. The study was extended to the tertiary ammonium carboxlates in order to clarify the difference in ionic association between tertiary and quaternary ammonium salts.

The conductometric analysis of tertiary ammonium salts in $\gamma$-butyrolactone has not been reported and only the data for diethylammonium salicylate ${ }^{15.16)}$ (secondary ammonium salt) have been published.

\section{EXPERIMENTAL}

Triethylammonium bimaleate, biphthalate and benzoate were prepared in situ by the neutralization of maleic acid, phthalic acid and benzoic acid with triethylamine in $\gamma$-butyrolactone. Triethylammonium perchlorate was prepared by the titration of aqueous perchloric acid with triethylamine followed by recrystallization and vacuum drying.

The water content in the mother solutions (less than $100 \mathrm{ppm}$ ) was measured by a moisture meter and the concentrations of the solutions were calibrated. The

Tsukuba Research Centre, Mitsubishi Petrochemical Co., Ltd., (8-3-1 Chuo, Ami, Inashiki, Ibaraki 300-03, Japan)

Key Words: Conductivity, Association Constant, Ammonium Carboxylate, $\gamma$-Butyrolactone conductivity measurements were carried out by the method previously reported ${ }^{13)}$.

\section{RESULTS AND DISCUSSION}

The molar conductivities $\Lambda$ of the mother solutions (C; $\left.1 \mathrm{~mol} \mathrm{dm}{ }^{-3}\right)$ and diluted solutions $\left(10^{-2}\right.$ to $10^{-3} \mathrm{~mol}$ $\mathrm{dm}^{-3}$ ) are given in Table 1 and Fig. 1, respectively.

The molar conductivities of the tertiary ammonium salts are evidently lower than those of the quaternary ammonium counterparts having the same formula weights due to ionic association.

\section{Analysis of conductivity data}

The conductivity dlata were analyzed by means of the Fernández-Prini expansion of the Fuoss-Hsia equation ${ }^{2}$ :

$$
\begin{aligned}
\Lambda=\Lambda_{0} & -S(C \gamma)^{1 / 2}+E(C \gamma) \ln (C \gamma)+J_{1}(C \gamma) \\
& -J_{2}(C \gamma)^{32}-K_{A}(C \gamma) f_{ \pm}^{2} \Lambda
\end{aligned}
$$

where $\Lambda_{0}, K_{A}, \gamma$ and $f_{ \pm}$are the limiting molar conductivity, the association constant, the degree of dissociation and the mean molar activity coefficient, respectively. All the coefficients $S, E_{1} J_{1}$ and $J_{2}$ depend on the solvent properties and the charge on the ions, and $J_{1}$ and $J_{2}$ also depend on the distance $R$ of closest approach of ions.

The mean molar activity coefficient was calculated by the Debye-Hückel equation ${ }^{3)}$ :

$$
\text { In } f_{ \pm}=-A(C \gamma)^{1 / 2} /\left[1+B R(C \gamma)^{1 / 2}\right]
$$

The association constant was evaluated according to the mass action equation ${ }^{3)}$ :

$$
K_{A}=(1-\gamma) / C \gamma^{2} f_{ \pm}^{2}
$$

where the activity coefficient for the neutral ion pair is assumed to equal unity.

Although the distance parameters $R\left(J_{1}\right)$ and $R\left(J_{2}\right)$, which are derived from $J_{1}$ and $J_{2}$, must be compatible with $R$ in equation 2 , there exists inconsistency between distance parameters. Justice recommended that $R\left(J_{1}\right)$ and $R$ be set equal to the Bjerrum critical distance $q^{17}$. 
Fernández-Prini suggested further that the best results for slightly associated electrolytes are obtained by fixing these parameters, and they are set equal to $q$, when association is assumed to be of electrostatic nature ${ }^{2,18}$.

Setting the distance parameter Requal to the Bjerrum critical distance $q$, a two-parameter $\left(\Lambda_{0}\right.$ and $\left.K_{A}\right)$ equation 1 was solved by an iterative least square method $^{2)}$. The standard error of estimate $\sigma_{\Lambda}$ is defined by the following equation ${ }^{2)}$ :

$$
\sigma_{\Lambda}=\left[\Sigma\left(\Lambda_{\text {obsd }}-\Lambda_{\text {calcd }}\right)^{2} /(n-2)\right]^{1 / 2}
$$

Limiting molar conductivities and association constants

The results are given in Table 2 , where the parameters for diethyldimethylammonium salts were obtained by reanalyzing the conductivity data in Ref. 13.

Lower limiting molar conductivities were obtained

Table 1 Molar conductivities in GBL at $1 \mathrm{~mol} \mathrm{dm}^{-3}$ and $25^{\circ} \mathrm{C}$

\begin{tabular}{|c|c|c|c|}
\hline$\Lambda$ & $\pi_{\mathrm{COOH}}^{\mathrm{COO}}$ & & B. \\
\hline $\mathrm{Et}_{3} \mathrm{NH}^{+}$ & 4.1 & 3.2 & 0.4 \\
\hline $\mathrm{Me}_{2} \mathrm{Et}_{2} \mathrm{~N}^{+}$ & $13.7^{*}$ & $10.8^{*}$ & $6.0^{*}$ \\
\hline
\end{tabular}

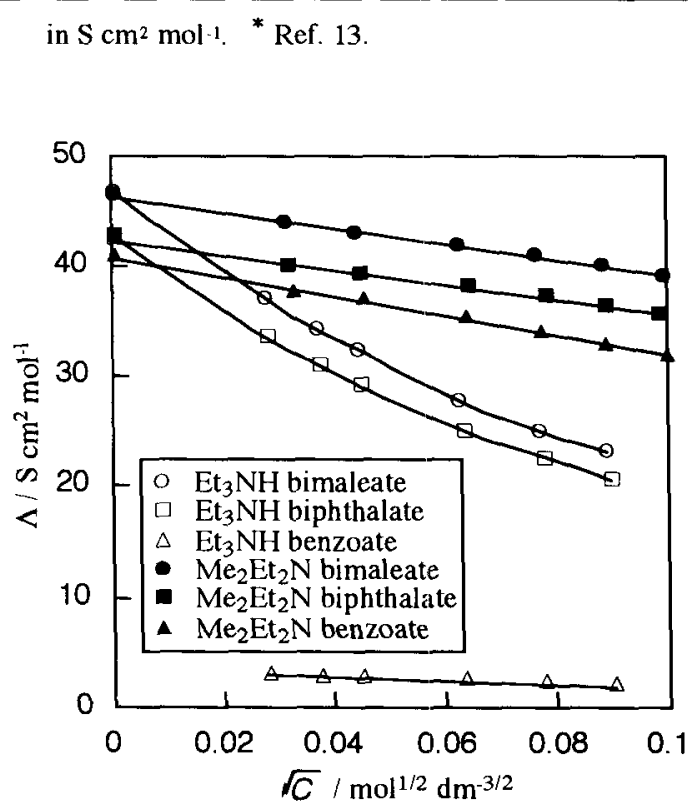

Fig. 1 Kohlrausch plots for tertiary and quaternary ammonium carboxylates in GBL at $25^{\circ} \mathrm{C}$. for tertiary ammonium salts due to the large association constants. Therefore, their limiting molar conductivities were estimated from the data of $\mathrm{Et}_{3} \mathrm{NHClO}_{4}$, which showed a slight association $\left(\Lambda_{0}=\right.$ $48.9 \mathrm{~S} \mathrm{~cm}^{2} \mathrm{~mol}^{-1}, K_{A}=11.0 \mathrm{dm}^{3} \mathrm{~mol}^{-1}$ ). The obtained differences of $\Lambda_{0}\left(\mathrm{Et}_{3} \mathrm{NHClO}_{4}\right)-\Lambda_{0}\left(\mathrm{Et}_{4} \mathrm{NClO}_{4}\right)^{19)}=1.1 \mathrm{~S}$ $\mathrm{cm}^{2} \mathrm{~mol}^{-1}$ and $\lambda_{0}\left(\mathrm{Et}_{2} \mathrm{Me}_{2} \mathrm{~N}^{+}\right)-\lambda_{0}\left(\mathrm{Et}_{4} \mathrm{~N}^{+}\right)=1.4 \mathrm{~s} \mathrm{~cm}$ $\mathrm{mol}^{\left.-1{ }^{13}\right)}$ give $\lambda_{0}\left(\mathrm{Et}_{3} \mathrm{NH}^{+}\right)-\lambda_{0}\left(\mathrm{Et}_{2} \mathrm{Me}_{2} \mathrm{~N}^{+}\right)=-0.3 \mathrm{~S} \mathrm{~cm}^{2}$ $\mathrm{mol}^{-1}$. The estimated values are given in parentheses in Table 2 .

The revised single ion limiting molar conductivities are also presented in Table 3.

The association constants of the triethylammonium salts were more than 20 times higher than those of the corresponding diethyldimethylammonium salts. Extraordinarily large ionic association prohibited the simple calculation for the triethylammonium benzoate.

This behavior can be ascribed to the hydrogen bond effect of a protic cation. It is evident that there is a large difference in ionic association between protic cation (tertiary ammonium ion) and non-protic cation (quaternary ammonium ion) in dipolar aprotic solvents.

Table 2 Derived parameters in GBL at $25^{\circ} \mathrm{C}$.

\begin{tabular}{|c|c|c|c|}
\hline Salt & $\Lambda_{0}$ & $K_{A}$ & $\sigma_{\Lambda}$ \\
\hline $\mathrm{Et}_{3} \mathrm{NH}$ & $\begin{array}{c}43.6 \\
(46.1)\end{array}$ & 226 & 0.099 \\
\hline $\mathrm{Me}_{2} \mathrm{Et}_{2} \mathrm{~N}$ & 46.4 & 10 & 0.140 \\
\hline $\mathrm{Et}_{3} \mathrm{NH}$ & $\begin{array}{c}39.7 \\
(42.2)\end{array}$ & 228 & 0.047 \\
\hline $\mathrm{Me}_{2} \mathrm{Et}_{2} \mathrm{~N}$ & 42.5 & 10 & 0.110 \\
\hline
\end{tabular}

$\Lambda_{\mathrm{o}}$ in $\mathrm{S} \mathrm{cm}^{2} \mathrm{~mol}^{-1}, K_{\mathrm{A}}$ in $\mathrm{dm}^{3} \mathrm{~mol}^{-1}$.

Table 3 Single ion limiting molar conductivities in $\mathrm{GBL}$ at $25^{\circ} \mathrm{C}$.

\begin{tabular}{llll}
\hline$\lambda_{0}{ }^{+}$ & & $\lambda_{0}^{-}$ \\
\hline $\mathrm{Et}_{3} \mathrm{NH}^{+}$ & 20.4 & {$\left[_{\mathrm{COOH}}^{\mathrm{COO}-}\right.$} & 25.7 \\
$\mathrm{Me}_{2} \mathrm{Et}_{2} \mathrm{~N}^{+}$ & 20.7 & $\mathrm{ClO}_{4}^{-} \mathrm{COOH}^{-}$ & 21.8 \\
$\mathrm{Et}_{4} \mathrm{~N}^{+}$ & $19.3^{*}$ & $\mathrm{ClO}_{4}^{-}$ & $28.5^{*}$ \\
\hline
\end{tabular}

in $\mathrm{S} \mathrm{cm}^{2} \mathrm{~mol}^{-1}$. ${ }^{*}$ Ref. 19 


\section{REFERENCES}

1) R. A. Robinson and R. H. Stokes, Electrolyte Solutions, 2nd ed. rev., Butterworths, London (1970)

2) A. K. Convington and T. Dickinson, ed., Physical Chemistry of Organic Solvent Systems, Plenum Press, London (1973).

3) O. Popovych and R. P. T. Tomkins, Nonaqueous Solution Chemistry, Wiley, New York (1981).

4) A. D'A prano, D. I. Donato and A. Carrubba, $J$. Solution Chem., 12, 209 (1983)

5) M. Salomon and E. J. Plichta, Electrochim. Acta, 29, 731 (1984).

6) M. Salomon and E. J. Plichta, Electrochim. Acta, 30, 113 (1985).

7) S. Tobishima and T. Okada, Electrochim. Acta, 30, 1715 (1985).

8) L. Werblan, A. Balkowska, J. Lensinski and G. Szymanski, J. Electroanal. Chem., 250, 165 (1988).
9) A. Balkowska, G. Szymanski and L. Werblan, $J$. Electroanal. Chem., 287, 229 (1990).

10) A. Balkowska, J. Lensinski, G. Szymanski and L. Werblan, J. Electroanal. Chem., 289, 171 (1990).

11) M. Ue, T. Sato, H. Asahina, K. Ida and S. Mori, Denki Kagaku, 60, 480 (1992).

12) K. Matsuki, A. Sawaguchi and M. Sugawara, Denki Kagaku, 60, 488 (1992).

13) M. Ue, T. Sato and M. Takeda, Denki Kagaku, 61, 1080 (1993).

14) M. Ue, K. Shima and S. Mori, Electrochim. Acta, in press.

15) A. I. Shcherban, I. V. Perevertkina and G. V. Kharitonov, Zh. Obshch. Khim., 58, 270 (1988).

16) A. I. Shcherban, I. V. Perevertkina and G. V. Kharitonov, Zh Obshch. Khim., 58, 273 (1988).

17) J. C. Justice, Electrochim. Acta, 16, 701 (1971).

18) P. M. McDonagh and J. F. Reardon, J. Solution Chem., 19, 301 (1990).

19) M. Ue, J. Electrochem. Soc., 141, 3336 (1994). 